\title{
Performance characteristics of rabbits fed some wild evergreen forages
}

Ukorebi, B. A., Gboshe, P. N and Meremikwu, V. N

Department of Animal Science, Faculty of Agriculture and Forestry,

Obubra Campus, Cross River University of Technology,

Cross River State, Nigeria.

Abstract

Corresponding author:- basseyukorebi@gmail.com +2347039830849

A ten-week trial was conducted to examine the effect of feeding four wild forages (Daniella oliveri, Sarcopcephalus latifolia, Vitex doniana and Ficus thoningii) on the performance characteristics of rabbits; the four forages constituted treatments $1-4$, respectively. Twenty four unsexed rabbits of mixed breeds aged, between four and five weeks with average weight of $514 \mathrm{~g}$ were used for the study. The animals were randomly allotted to the four treatments, each with three replicates of two rabbits per replicates. The parameters measured were, feed intake, weight gain, feed conversion ratio, carcass parts and organs weights. The results of the proximate composition especially crude protein $(C P)$ and crude fibre $(C F)$ were within the ranges of $15-30 \% \mathrm{CP}$ and 20-45\% CF respectively as recommended for optimum performance of rabbits. The results of the performance generally showed positive growth response as all the forages had potentials for supporting rabbit growth. The live weight gain and feed intake of experimental rabbits were significantly different $(P<0.05)$. However, feed conversion ratio was not significantly $(p>0.05)$ affected by the treatments. No health hazards of any nature were encountered throughout the experiment which may imply that these forages apart from supporting growth may also be medicinal. From the results, the best of the forages, viewed from the performance perspective, appears to be Ficus thoningi, which suggests that it may have supplied adequate nutrients that may be lacking in grassland pastures in the dry season, it is therefore recommended for feeding of growing rabbits.

Keywords: wild forages, rabbits, performance characteristics,

\section{Introduction}

The search for alternative cheap sources of feed to improve the scope of animal production which may as well increase the amount of protein intake by Nigerians, continue to challenge the professionals in livestock farming in Nigeria. Feeding of browse forages to animals especially in the dry season is essential when grasses and herbaceous legume forages are scarce. Daniella oliveri, Sarcophalus, latifolia, Vitex doniana and Ficus thoningii could solve this problem. This is because these plants are perennial, and their leaves are available and remain green all year round. Indeed, they seem to be even luxuriant at the peak of the dry season. Adegbola and Oduozo (1992) and Alawa and Amandi (1991) opined that some of the limiting factors associated with using browse plants as animal feeds include procurement, storage, high fibre content, toxic substances, poor feed intake, poor digestibility and consequent low performance of the animals. There is need to further investigate the use of these browse plants because of their availability as alternative feed resources to livestock, as only scanty information is available on their nutrient composition. Tegbe et al. (2004) reported that the proximate composition $\mathrm{g} / 100 \mathrm{~g}$ ) of dried Ficus leaf meal have $40.61 \%$ dry matter, $18.51 \%$ crude protein, $19.41 \%$ crude fibre, $5.57 \%$ ether extract and $10.87 \%$ ash. These values were similar to the data reported by Bamikole et al. (2001). The authors also indicated that the mean crude protein content of Ficus species were consistent with the report of Le Houreou (1980) on the crude protein of browse plants in tropical West Africa; adding that the level of $\mathrm{CP}$ in Ficus is higher than the critical 


\section{Performance characteristics of rabbits fed some wild evergreen forages}

level of $7 \mathrm{~g} / 100 \mathrm{~g}$ Dm at which feed intake of the animal is depressed (Minison, 1990). Bamikole et al. (2001) reported that Ficus species have good levels of nutrients particularly protein for livestock feeding and that the level of anti-nutritional factors is low with a guaranteed good acceptability by foraging livestock. Abejeshi et al. (2017) in their preliminary study of these tropical wild forages on the feeding of rabbits reported the proximate composition of the forages to be in the range of crude protein of 8.75 to $18 \%$. This is in agreement with the range of 5.00 to $35.00 \%$ reported by Cheeke and Shull (1984) for tropical forages, it is comparable to the range reported by Shane (2012) of 7.00 to $28 \%$ for most forages. The CF range of 7.32 to 22.08 was a bit lower than the value 9.00 to $30.0 \%$ obtained by Cheeke and Shull (1984) and that reported by Shane (2012) of 9.0 to $37 \%$. The EE range of 2.00 to $6.41 \%$ the forages was also within the range of 1.5 to $12.00 \%$ reported by (Shane, 2012). These differences observed could be attributed to variations in location and varieties of forages.

It was therefore, the focus of this present study to evaluate the feeding value the leaves of these four wild plant species: Daniella oliveri Sarcocephalus latifolia Vitex doniana and Ficus thoningii in rabbit production. It is important to note that the leaves of these plants are available all year round and even luxuriant at the peak of dry season. This

investigation will determine the extent to which they can sustain rabbits and add to the range of forages that can be fed to the animals.

\section{Materials and methods \\ Source and production of the forages}

The wild forages, Daniella oliveri, Sarcocephalus latifolia, Vitex doniana and Ficus thoningii were harvested from the neighboring villages of Obubra community, where the Cross River University, Faculty of Agriculture and Forestry is located. The freshly cut forages were wilted overnight and fed to the rabbits in their various treatments, T1, T2, T3 and T4 respectively of, Daniella oliveri, Sarcophalus, latifolia, Vitex doniana and Ficus thoningii. Supplementary concentrate was offered at $2 \%$ of their weekly live body weight.

\section{Biochemical analysis}

Samples of the leaves were subjected to proximate analysis according to A.O.A.C. (2005) methods (Table 1).

\section{Anti-nutritional factors of the browse plants}

Phytate in the leaves was estimated as phytic acid using the method of Maga (1982) and by titration method described by Wheeler and Ferrei (1971). Saponin was determined gravimetrically by the method of Oduguwa et al. (1998) as reported by Babayemi et al. (2004) and Makkar and Goodchild (1996). Oxalate was determined titrimetrically as described by Chima and Igyor (2007), Tannin was determined using the methods described by Bohm and Kocipai (1994). Alkaloid was determined by the method described by Harbone (1973).

\section{Experimental design}

Twenty four unsexed mixed breed weaned rabbits of about 4 and 5 weeks of age were randomly assigned to four treatments groups of six rabbits each in a completely randomized design. T1 group was offered Daniella oliveri, while T2, T3 andT4 groups were fed Sarcocephalus latifolia, Vitex doniana and Ficcus thoningii, respectively. Each treatment group was further sub-divided into three replicates of two rabbits per replicate.

\section{Management of experimental rabbits}

Twenty four mixed breeds crossbred weaned rabbits of about 4 and 5 weeks of age, with initial average weight of 514 $\pm 9.93 \mathrm{~g}$, were used in this study. The animals were randomly allocated to four treatments groups, each with three 


\section{Ukorebi, Gboshe and Meremikwu}

replicates of two rabbits per replicate and balanced for initial weights. The test forages which were randomly assigned to the groups consisted of freshly cuts and wilted forages of Daniella oliveri, Sarcocephalus latifolia, Vitex doniana and Ficus thoningii. Supplementary concentrate was offered at $2 \%$ of their weekly body weight). The rabbits on arrival were allowed a preliminary feeding period of seven days for stabilization. They were then weighed and randomly allocated to the treatments. Two rabbits in a treatment which served as a replicate were housed in wire mesh in well-cleaned and disinfected hutch measuring $60 \times 40 \times 40 \mathrm{~cm}$ containing a feeder and a drinker. Standard health and sanitation procedures were strictly observed during the experimental period.

Three days was allowed for adjustment by the rabbits on both forages and concentrate feeding. Rabbits were fed in the morning (7.00 - 8.15 am). Clean fresh water was offered ad-libitum throughout the experimental period of twelve weeks.

\section{Experimental procedure/parameters} measured

\section{Average daily feed intake}

The rabbits in each replicate were fed weighed amounts of their group forage daily. Feed intake was determined by obtaining the differences between the quantity of feed offered and the left over weekly. The average daily feed intake of all the rabbits was obtained by dividing the total feed intake of the rabbits during the period under study by 84 days.

\section{Average daily weight gain}

The animals were weighed at the beginning of the experiment and weekly thereafter to obtain the weekly weight in order to determine the growth rate. The growth rate was obtained by subtracting the initial weight from the final weight of each rabbit and this was divided by 84 days to get the average daily weight gain per rabbit.

\section{Feed Conversion Ratio (FCR)}

The average daily feed intake was divided by average daily weight gain to obtain the feed conversion ratio.

$\mathrm{FCR}=$ Weight of feed intake: Weight gain

\section{Statistical analysis}

Data generated on the various parameters were subjected to analysis of variance (ANOVA), the procedure outlined in Minitab statistical package. Where significant difference were indicated, the means were ranked using the least significant difference (LSD) contained in the Minitab statistical software.

\section{Results}

\section{The proximate composition of the forages}

The proximate composition of the forages used in the study is presented in Table 1. Anti-nutritional factors of experimental browse plant leaves used for the study are presented in Table 2.

Table 1. Proximate composition (g/100g) of the four wild forages (DM) \%

\begin{tabular}{lccccccc}
\hline & $\mathrm{DM}$ & $\mathrm{CP}$ & $\mathrm{CF}$ & $\mathrm{ASH}$ & $\mathrm{EE}$ & $\mathrm{NFE}$ & $\mathrm{ME}(\mathrm{kcal} / \mathrm{kg})$ \\
\hline $\begin{array}{l}\text { Daniella oliveri } \\
\text { Sarcocephalus }\end{array}$ & 41.80 & 21.88 & 26.15 & 7.45 & 4.35 & 40.17 & 2935.50 \\
latifolia & 32.60 & 19.53 & 35.60 & 5.65 & 2.20 & 27.07 & 2494.90 \\
Vitex doniana & 40.96 & 17.50 & 36.70 & 5.15 & 2.55 & 38.10 & 2528.70 \\
Ficus thoningii & 27.91 & 26.25 & 44.40 & 13.90 & 5.20 & 10.25 & 1923.70 \\
\hline DM= dry matter, $C P=$ crude protein, $C F=$ crude fibre, EE = ether extract, NFE = nitrogen extract. and $M E=$ Metabolizable energy.
\end{tabular}




\section{Performance characteristics of rabbits fed some wild evergreen forages}

Table 2: Anti-nutritional factors of experimental browse plant leaves

\begin{tabular}{lcccc}
\hline $\begin{array}{l}\text { Anti-nutrient } \\
(\mathrm{mm} / \mathrm{l} 00 \mathrm{~g})\end{array}$ & Ficus thoningii & Vitex doniana & Daniella oliveri & \multicolumn{2}{c}{$\begin{array}{c}\text { Sarcopcephalus } \\
\text { latifolia }\end{array}$} \\
\hline Tannin & 1.22 & 2.34 & 5.1 & 0.34 \\
Phytate & 4.02 & 0.18 & - & 0.42 \\
Oxalate & 12.3 & 0.39 & - & - \\
Saponins & 3.60 & - & 0.002 & 1.25 \\
Alkaloids & - & 0.89 & 0.001 & 2.38 \\
\hline $\mathrm{Ft}=$ Ficcus thoningii, $\mathrm{Vd}=$ Vitex doniana , Do= Daniella oliveri, Sl= Sarcocephalus latifolia $(-)=$ not present
\end{tabular}

Percentage and calculated nutrient composition of the formulated concentrate

Table 3 shows the percentage and calculated nutrient composition of the concentrate diets. The crude protein of the concentrate diet was $15 \%$ which was similar to $(\mathrm{p}<0.05)$ the value recommended by Aduku (2012) for growing rabbits but
$\mathrm{ME} / \mathrm{Kcal} / \mathrm{kg}$ of 2986 differ ( $\mathrm{p}>0.05$ ) from that of Aduku (2012) $2400 \mathrm{ME} / \mathrm{kcal} / \mathrm{kg}$. All other nutrients calculated were also not similar $(\mathrm{p}>0.05)$ to values recommended by this author.

Performance characteristics of the rabbit fed the forages for 12 weeks

The performance traits of the rabbit fed the forages for 12 weeks is showed in Table 4

Table 3. Percentage and calculated nutrient composition of the formulated concentrate.

\begin{tabular}{lc}
\hline Ingredients & $\%$ inclusion \\
\hline Maize & 48.00 \\
Full-fat soybean & 24.00 \\
Rice husk & 15.00 \\
Rice offal & 10.00 \\
Bone meal & 2.00 \\
Common salt & 0.50 \\
Vitamin premix ${ }^{+}$ & 0.50 \\
Calculated nutrient composition. & \\
Crude protein (\%) & 15.00 \\
Metabolizable energy (kcal/kg) & 2986.00 \\
Crude fibre (\%) & 5.60 \\
\hline$*$ Each Ikg of vitamin/mineral premix manufactured by BEAUTS Co. Inc. Man, U.S.A, contains Vitamin A 220,000, Vitamin D 66,000, Vitamin \\
E 44, 014; Vitamin k 88 mg; Vitamin K 88 mg; Vitamin B 12; 0.76 mg; Niacin 1122 mg, calcium 27\% phosphorus 10\% Iron 0.6\%, Zinc 0.35\%, \\
Manganese 0.25\%, Copper 0.06\%; Iodine 0.002\%, Cobalt 26 ppm, selenium 4 pp. ME = Metabolizable Energy.
\end{tabular}

Table 4: Performance characteristics of the rabbit fed wild forages for 12 weeks

\begin{tabular}{lccccc}
\hline Items & $\mathrm{T}_{1(\mathrm{DO})}$ & $\mathrm{T}_{2(\mathrm{SL})}$ & $\mathrm{T}_{3(\mathrm{VD})}$ & $\mathrm{T}_{4(\mathrm{FT})}$ & $\mathrm{SEM}$ \\
\hline Initial weight $(\mathrm{g})$ & 517 & 542 & 500 & 500 & \\
Final weight at slaughter $(\mathrm{g})$ & $950^{\mathrm{b}}$ & $950^{\mathrm{b}}$ & $950^{\mathrm{b}}$ & $1375^{\mathrm{a}}$ & 4.21 \\
Total feed intake $(\mathrm{Dm})(\mathrm{g})$ & $3587^{\mathrm{c}}$ & $3377^{\mathrm{c}}$ & $4113.8^{\mathrm{b}}$ & $5144^{\mathrm{a}}$ & 166.0 \\
Daily feed intake $(\mathrm{DM})(\mathrm{g})$ & $51.24^{\mathrm{c}}$ & $48.24^{\mathrm{c}}$ & $58.77^{\mathrm{b}}$ & $73.48^{\mathrm{a}}$ & 83.0 \\
Total weight gains $(\mathrm{g})$ & $433.3^{\mathrm{b}}$ & $375^{\mathrm{b}}$ & $416.7^{\mathrm{b}}$ & $800^{\mathrm{a}}$ & 100.9 \\
Daily weight gain $(\mathrm{g})$ & $6.19^{\mathrm{b}}$ & $5.36^{\mathrm{b}}$ & $5.95^{\mathrm{b}}$ & $11.4^{\mathrm{a}}$ & 50.45 \\
Feed : gain & 8.270 & 9.00 & 9.87 & 6.43 & 3.35 \\
Mortality (\%) & 0.00 & 0.00 & 0.00 & 0.00 & \\
\hline
\end{tabular}

$\mathrm{a}, \mathrm{b}, \mathrm{c}$, means on the same row with same superscript are not significantly different $(\mathrm{p}>0.05)$

SEM $=$ Standard error of means 


\section{Ukorebi, Gboshe and Meremikwu}

\section{Discussion \\ Proximate composition of the wild forages}

The proximate composition of the wild forages used in this study, (Table 1) are generally comparable to the nutrients values of the forages, especially $\mathrm{CP}$ and $\mathrm{CF}$ which were within the ranges of $15-30 \% \mathrm{CP}$ and $20-45 \%$ CF (Aduku, 2012). This however, is against the $\mathrm{CP}$ and $\mathrm{CF}$ values of $12-22 \%$ and $16-26 \%$ respectively obtained by Ugwuene (2003) and $12-16 \% \mathrm{CP}$ and $15-25 \%$ CF obtained by Shiawoya and Adams (2004) for tropical forages. There were also within the range of crude protein of 8.75 to $18 \%$ reported of the browse plant use in the experiment (Abejeshi et al., 2017) and within the range of 5.00 to $35.00 \%$ reported by Cheeke and Shull (1984) for tropical forages and was also within the range reported by Shane (2012) of 7.00 to $28 \%$ for most forages. The CF range of 26.15 to 44.40 was higher than 7.32 to 22.08 (Abejeshi et al., 2017), but comparable to a value of 9.00 to $30.0 \%$ obtained by Cheeke and Shull (1984) and 9.0 to $37 \%$ reported by Shane (2012). Aduku and Olukosi (1990) observed that the range of fibre required in rabbit diets reflects a high requirement for forage in the diet for optimum growth.

The EE range of 2.00 to $6.41 \%$ present in experimental forages was also within range of 1.5 to $12.00 \%$ reported by Abejeshi et al. (2017) and Shane (2012). These few differences are attributable to variations in location and varieties of forages.

\section{Anti-nutritional factors of experimental forages}

The anti-nutritional factors of experimental browse plant leaves are shown in Table 2. The percentage components of antinutritional factors in this present study were low but comparable to the reports of Biobaku (1994) and Mbomi et al. (2011). Among the anti-nutritional factors, the tannin content of 1.22, 2.34, 5.1 and 0.34 obtained in Ficcus thoningii, Vitex doniana,
Daniela oliveri, and Sarcocephalus latifolia respectively were comparable to values of 0.13 to $6.31 \%$ reported previously by George (2003). A threshold concentration of $5 \%$ tannin had been reported, above which there is rejection of browse plants by goats (Ologhobo,1989). The phytin levels reported in this study ranged from 0.42 to $4.02 \mathrm{~mm} / 100 \mathrm{~g}$, which was lower than the values 13.80 to 25.20 $\mathrm{mm} / 100 \mathrm{~g}$ reported by Okoli et al. (2003) for the south-eastern browses in Nigeria. These levels are unlikely to have any adverse effects on animals. The oxalate content of the browse species was not consistent with the reported values (1.49 to $5.79 \%$ ) of some browse plants relished by ruminants in Nigeria (Fadiyimu et al., 2011). Oxalate content in this present study was low. It has been reported that $20 \mathrm{~g} / \mathrm{kg}$ oxalate can be lethal to chicken (Acamovic et al., 2004). The saponin content of 0.002$2.55 \mathrm{~mm} / 100 \mathrm{~g}$ was also low as in other leguminous browse species. Report from Oduguwa et al. (1998) shows values of $3.24 \%$ and $3.47 \%$ for Parkia biglobosa and Afzelia africana respectively. Feedstuffs containing saponin had been shown to be defaunating agents (Teferedegne, 2000). Cheeke (1971) reported that saponin has effect on erythrocyte haemolysis, reduction of blood and liver cholesterol, depression of growth rate, bloat (in ruminants), inhibition of smooth muscle activity, enzyme inhibition and reduction in nutrient absorption. Saponins have been reported to alter cell wall permeability and therefore, produce some toxic effect when ingested (Belmar, 1999). The anti-nutritional effects of saponins have been mainly studied using alfalfa saponins. Sharma, and Chandra (2001) observed that 4 to 7 weeks of $a d$ libitum feeding of albizia gave rise to toxic manifestations in sheep. Symptoms included listlessness, anorexia, weight loss and gastro-enteritis. The toxicity of saponins can be reduced by repeatedly 


\section{Performance characteristics of rabbits fed some wild evergreen forages}

soaking the feed in water, though the level recorded in this present study may not pose any problem to the animals.

\section{Experimental concentrate and its calculated composition}

The experimental composition and its calculated composition as presented in Table 3 showed that the calculated composition values obtained for crude protein, crude fibre and Metabolizable energy for the experimental concentrate apart from $\mathrm{CP}$, did not fall within the value ranges of 14 to $16 \% \mathrm{CP}, 14$ to $25 \% \mathrm{CF}$ and 2400 to $2700 \mathrm{kcal} / \mathrm{kg} \mathrm{ME}$ required for optimum growth and performance in rabbits (Aduku, 2012).

\section{Performance of rabbits fed the wild browse plant}

The data on feed intake, weight gain, feed conversion ratio and mortality rate are presented in Table 4. The feed intake differed significantly $(\mathrm{p}<0.05)$. The dry matter (DM) intake was highest in rabbits fed Ficus thoningii and lowest on the those fed Daniella oliveri leaves. The highest consumption of Ficus thoningii could have been due to its succulent and palatable nature. This agreed with the findings of Aduku et al. (1986) and Asuquo (1997) that leafier succulent greens are often preferred by rabbits. As indicated by the results of the chemical composition (Table 2), Ficus thoningii has the lowest Dm (27.91\%) and the highest moisture content (72.09\%) which could be responsible for its relatively high feed intake in this study. This also could be due to the high crude fibre and ash content that suggests that the Metabolizable energy (ME) would be low, thus the rabbits consumed more Ficus thoningii feed in order to satisfy their energy requirements. This also agrees with the observations of Taiwo et al. (2004) on forage intake. This high FT intake could also be as a result of its high content of critical nutrients and its palatability as was observed by Aduku and Olukosi (1990). The figures reported here:
5.36 to $11.43 \mathrm{~g}$ for average daily gain were lower than 12.91 to $17.96 \mathrm{~g} /$ day/rabbit reported by Abejeshi et al. (2017) when they worked on some tropical evergreen browse plants. They are also lower than 18.20 to $19.20 \mathrm{~g} /$ day/rabbit reported by Aduku et al. (1988) but they fall within the range of 10 to $20 \mathrm{~g} /$ day/rabbit which George (2003) found to be normal for most rabbits reared in the tropical environment.

The performance of the rabbits fed different types of forages as shown in Table 3, indicated that, all the rabbits showed positive growth rates. Body weight gain of the rabbit also increased in this order Ficus thoningii > Daniella oliveri > Sarcocephalus latifolia $>$ Vitex doniana. The results were significantly different $(p<0.05)$. The highest weight gains were seen on rabbits fed Ficus thoningii. This could be as a result of its high nutrients content such as ash, 13.90\%; EE, 5.20\%; CP $26.25 \%$ and CF, $44.40 \%$ which are required for optimum growth rate of rabbits.

Feed conversion ratio was however, not significantly different $(\mathrm{p}<0.05)$ as was observed in DM intake and weight gains. It ranged from 6.43-9.87 with the best on rabbits fed Ficus thoningii (6.43) which shows that the rabbits fed this forage were able to convert it to flesh which was actually showed in the highest weight gain. The feed conversion ratios obtained in this study were higher than 3.08 to 3.69 reported by Asar (2010) and also not in agreement with the values 4.81 to 6.0 obtained by Nworgu and Ogbosuka (2003).

\section{Conclusion}

The study showed that the proximate composition of the wild forages had good nutrient profiles with low levels of antinutritional factors which did not interfere with nutrient absorption by rabbits. The study portrayed that all the forages could support rabbit growth as was observed in 


\section{Ukorebi, Gboshe and Meremikwu}

their performance even when concentrates was supplemented at the level of just $2 \%$ of weekly live body weights of the rabbits. Most importantly in the feeding trial of these forages, no health hazards of any nature was encountered throughout the experiment which may imply that these forages apart from supporting growth, may also be medicinal. Based on performance however, Ficus thoningii was more favoured so could therefore be actively encouraged in the feeding of growing rabbits.

\section{References}

Abejeshi, I. M., Okwori, A. I., Shaahu, D. T., Enaku, O. O.2018. Effect of feeding some evergreen tropical browse plant leaves on performance, digestibility and economic analysis of growing rabbits. Nigerian Journal of Animal Science 20 (1) 200-211.

Acamovic, T., Steward, C. S. and Pennycott, T. W. (eds) 2004. Poisonous plants and related toxins. Oxford University Press, $608 \mathrm{pp}$

Adegbola, T.A. and Oduozo, P.C 1992. Nutrient intake, digestibility and performance of rabbits Fed varying levels of fermented and unfermented cassava peel meal, Journal Animal production. Res 12(1) $41-47$.

Aduku, A. O. 2012. Animal Nutrition in the Tropics. Feeds and Feeding, pasture Management, Monogastric and Ruminant Nutrition. Davcon computer \& Business Bureau, No. 11 Calvary Baptist Church Rd. Samaru Zaria, Kaduna State, Nigeria. Pp 5:1718

Aduku, A.O. and Olukosi, J.O. 1990. Rabbit management in the topics; production, processing,
Utilization, Marketing, Economics, Practical, Training Research, and future prospects Gcl Publications, Abuja Nigeria PP33-68.

Aduku, A. O., Dim, N. I. and Aganga, A. A. 1988. Note on a comparative evaluation of palm kernel meal, peanut meal and sunflower meal in diets for weanling rabbits. Journal of Applied Rabbit Research, 11 (4): 264-266

Aduku, A.O., Okon, P.N., Njoku, P.C., Agange, A.A and Dim, N.I. 1986. Evaluation of Cowpea (vigna ungiculata) and peanut (Arachis hypogea) haulms as feedstuffs for weaning rabbits in tropical environment (Nigeria). Journal of applied rabbit RES. 9(4); 178-180

Alawa, J.P and Amandi, C. 1991. Voluntary feed intake and digestibility of diets containin corn Cobs brewer's dried grain and wheat bran by rabbits. Nigeria Journal. Animal production 11: 920.

A.O.A.C. 2005. The official methods of Analysis. Association of official analytical chemist. $5^{\text {th }}$ Ed. Washington, D.C

Asar, M. A., Mona, O. H., Yakout, $M$ and Safoat, A. 2010. Utilization of corn-cob meal and faba bean straw in growing rabbit's diets and their effects on performance, digestibility and economic efficiency. Egypt Poultry. Science. 30: 415-442.

Asuquo, B.O. 1997. Nutrient potentials of ipomea, Centrosema Pueraria, Emila and Tridax Forages in mixed feeds for weaner rabbits, Nigeria Journal. Animal production 24 (1);46-50.

Babayemi, O. J., Demeyer, D. and Fervez, V. 2004. Nutrition Value 
of quantitative assessment of secondary compounds in seeds of eight tropical browse, shrub and pulse legumes comm. Apply Biological Science Glint University, 69(1):103-110.

Bamikole, M.A., Ikhatua, U.J., Babayemi, O.J., Arigbede, 0 . M., Tela, I. E. and Osagie, P. 2001. Assessment of forage acceptability, some Nutritive and non- nutritive value component of Ficus species in Benin, Nigeria. Proceedings of the $26^{\text {th }}$ Annual conference of the Nigerian society for Animal production 26: 310313.

Belmar, R., Nava-Montero, R., Sandoval- Castro, C. and Menab, J. M. 1999. Jackbean (canuvaliaensiforms L. DC) in poultry diets: Anti-nutritional factors and detoxification studies. A. Review. Poultry Science Journal. 55 (1) 37-59.

Biobaku, W. O. 1994. Effects of feeding raw and cooked delonix ragia seed bean on the performance of rabbits. Journal of Agricultural Technology 7: 10- 14.

Bohm, A. B. and Kocipai, A. A. 1994. Flavonoids and condensed Tannis from leaves of Hawaiian Vaccinium vaticulation and $V$. calycinnium, Pacific Science, 48:458-453.

Cheeke, P.R. and Shull, L. R. 1984. Natural Toxicants in feeds and livestock. AVI publishing Incoporated, West port, Connecticut

Cheeke, P. R. 1971. Nutritional and Physiological implication Saponins: A Review. Canadian Journal of Animal Science 51: 621-623

Chima, C. E. and Igyor, M. A. 2007.
Micronutrient anti nutritional contents of selected tropical vegetable grown in southeast Nigeria, Nigeria food Journal 25(1):111-116

Fadiyimu, A. A., Fajemisin, A. N. and Alokan, J. A. 2011. Chemical composition of selected browse plants and their acceptability by West African Dwarf sheep. Livestock Research for Rural Development. Volume 23, Article \#256. Retrieved August 13, 2016, $\begin{array}{llll}\mathrm{f} & \mathrm{r} & \mathrm{o} & \mathrm{m}\end{array}$ http://www.1rrd.org//rrd23/12/fad i23256.htm

George 2003. The potentials of local vegetables in Nigeria. Hand book on Agriculture 2 (3): 80-86.

Harbone, Z. B. 1973. Phytochemical methods a guide to modern techniques of plant analysis. Chapman and Hall, London. pp. 113-185

Le Houerou 1980. Browse in Africa.The current state of knowledge. ILCA (International Livestock Centre for Africa).

Maga, J. A. 1982. Phytase, its chemistry, occurrence, food interaction, Nutritional significant methods of analysis. Journal of Agriculture food and Chemistry, 30:1-5

Makkar, A. O. S. and Goodchild, A. V. 1996. Qualification of tannins, a laboratory manual. International centre for Agricultural Research in the dry areas (ICARDA), Aleppo Syria.

Mbomi, S.E., Ogungbesan, A.M., Babayemi, O.J., Nchinda, N.P. 2011. Chemical composition, acceptability of three Tephrosia species and use of Tephrosia purprerea as supplement for grazing animals in the western highlands of Cameroon. Journal 


\section{Ukorebi, Gboshe and Meremikwu}

of Environmental Issues and Agriculture in Developing Countries. 3(3):132-138

Minson, D.J. 1990. Forage in Ruminant Nutrition. Academic press, New York.

Nworgu, F.C. and Ogbosuka, G.E. 2003. Ripe plantain (Musa paradisiaca) peels meal as an alternative energy source for weaned rabbits. 28th Annual Conference Nigeria Society Animal Institute of Agricultural Research Training, O.A.U. Ibadan. Ed(s).

Oduguwa, O.O., Oduguwa, B.O., Onwuka, C.F. I. and Olijobi, H.O. 1998. Anti-nutritional factors in foliage of some leguminous trees and shrubs. Proceedings of the silver Jubilee anniversary conference of the Nigeria Society for Animal Production, Abeokuta, Nigeria. pp. 339-340.

Okoli, I. C., Maureen, O., Anunobi, O., Obua, B. E. and Enemuo, V. 2003. Studies on selected browses of south-eastern Nigeria with particular reference to their proximate and some internal anti nutritional constituents. Livestock Res. Rural Dev. 15 (9): 3-7.

Ologhobo A. 1989. Mineral and antinutritional contents of forage and legumes consumed by goats in Nigeria. In: RT Wilson, A Melaku (Eds). Proceedings of a Conference on African Small Ruminant Research and Development, Bamenda, Cameroon

Shane G. 2012. Composition of some Livestock Feeds. University of Arkansas Cooperative Extension Service Printing Services.

Sharma, D. D. S. and Chandra, S. S.
2001. The nutritive value and toxicity of OHI (Albizia stipulate Bovin) tree leaves. J. Res. Ludlhiana 6:388-393.

Shiawoya, E.L. and Adams, O.O. 2004. Growth and carcas s characteristics of rabbits fed Mango leaves (manifera indica). Banana leaves (musa spp) and Tridax ( Tridax procubens) as Supplements to conventional feeds proceeding of the $29^{\text {th }}$ Annual conference of the Nigerian society for Animal production, 29: 172-175.

Taiwo, A.A., Adejuyigbe, A.A., Adebowale, E.A, Oshotan, J.S. and David,O.O. 2004. Effect of Tridax procumbens, Panicum maximum and paw paw leaves ( carica papaya) Supplemented with concentrate on the performance and nutrient digestibility of weaned Rabbits. Proceeding of the $29^{\text {th }}$ Annual conference of the Nigerian society for Animal Production, 29: 198-200.

Teferedegne, B. 2000. New perspectives on the use of tropical plants to improve ruminant nutrition. Production Nutrition Society, 59: 209-214.

Tegbe, T.S.R., Kaye, K.B., Alawa, J.P. and Adeyinka, L.A. 2004. Evaluation of feeding graded Levels of dried and milled Ficus thoningii leaves on growth performance, carcass Characteristics and organs of weaner rabbits. Proceeding of the $29^{\text {th }}$ Annual conference of the Nigerian society for Animal production $21 \mathrm{st}-25^{\text {th }}$ march, 2004, sokoto. 209

Ugwuene, M.C. 2003. Comparative performance of weaned rabbits 
Performance characteristics of rabbits fed some wild evergreen forages

fed conventional and Unconventional forages. Proc. Of

the $28^{\text {th }}$ Annual conference of the Nigeria society for Animal Production $16^{\text {th }}-20^{\text {th }}$ march, 2003. Ibadan 333-335

Wheeler, E. L. and Ferrei, R. E. 1971. A method for phytate acid determination in wheat and wheat fractions. Cereal chemistry, 48:312-320

Received: $16^{\text {th }}$ September, 2018

Accepted: $20^{\text {th }}$ February, 2019 